\title{
Tucupi creamy paste: development, sensory evaluation and rheological characterization
}

\author{
Telma dos Santos COSTA ${ }^{1}$, Juliana Rodrigues do CARMO ${ }^{1}$, Adriano Cesar Calandrini BRAGA², \\ Rosinelson da Silva PENA ${ }^{1,3 *}$
}

\begin{abstract}
Tucupi, a fermented product obtained from cassava (Manihot esculenta Crantz) is widely employed in the cuisine of the Northern region of Brazil, however, its industrial application is incipient. This study used tucupi to prepare a creamy paste, which underwent sensory and rheological evaluation. Paste formulations with 5 to $20 \%$ concentrated tucupi were obtained. An acceptance test was used to assess the product's acceptability regarding the attributes of color, aroma, flavor, texture, and overall impression. A purchase intention test of the product was also applied. The product's rheology was studied at 25,40 , and $60{ }^{\circ} \mathrm{C}$ and the activation energy $\left(\mathrm{E}_{\mathrm{a}}\right)$ was estimated. The internal preference mapping indicated that the paste formulation with $5 \%$ and $10 \%$ tucupi were the most accepted by the judge, but only the $10 \%$ tucupi paste was characterized. Proportions greater than $15 \%$ tucupi influenced negatively in the flavor and texture of the product. Purchase intention test showed that $99 \%$ of the judges demonstrated interest in purchasing the product. The product presented $72.7 \%$ moisture, $10.4 \%$ lipids, $0.5 \%$ proteins, $2.1 \%$ ashes, $14.3 \%$ carbohydrates, and $7.4 \mu \mathrm{g} / \mathrm{g} \beta$-carotene. According to the rheological assays, the paste presented characteristics of a pseudoplastic fluid. The Herschel-Bulkley model proved efficient to predict the flow curves for the product in the temperature range tested, for which $\mathrm{E}_{\mathrm{a}}$ was estimated at $7.49 \mathrm{~kJ} / \mathrm{mol}$.
\end{abstract}

Keywords: Manihot esculenta; cassava wastewater; $\beta$-carotene; preference mapping; rheology.

Practical Application: A creamy paste added with tucupi was obtained and characterized.

\section{Introduction}

Tucupi is a fermented product obtained from the liquid extracted from yellow cassava (Manihot esculenta Crantz), known in Brazil as manipueira. The product has unique flavor and is an important ingredient in the preparation of typical dishes of the cuisine from the Brazilian state of Pará, where it is also used to prepare sauces with pepper (Santos \& Pascoal, 2013; Soentgen \& Hilbert, 2016). Tucupi is an artisanal product that, overall, is little competitive given the small scale of production and the limited attention given to its presentation (Modesto \& Alves, 2014).

The development of industrialized paste and sauces must ensure its stability and sensory and rheological properties. Thus, the knowledge is necessary to identify the components and processes responsible for guaranteeing a quality product to consumers (Sikora et al., 2003). Commercial or homemade paste and sauce are acidified products that may contain water, vinegar, milk, vegetal oil, eggs, starch, and gums. Other constituents such as salt, sugar, garlic, pepper, vegetable extracts, and others may be added depending on consumer preference (Babajide \& Olatunde, 2010).

Products as creamy paste undergo pumping, sterilization, freezing, and acidification during processing, which may affect not only sensory characteristics, but also the product's rheological properties (Abdelrahim et al., 1994). Starch, a widely employed additive in the preparation of those food products as a thickening and gelling agent, may also cause considerable changes in those properties (Marques et al., 2006; Bortnowska et al., 2013). In order to control the rheological properties of starch-based products, the effects of process temperature on the products' rheology must be known (Nurul et al., 1999; Rao \& Tattiyakul, 1999; Lagarrigue \& Alvarez, 2001). The activation energy ( $\mathrm{E}_{\mathrm{a}}$ ) indicates the viscosity sensibility as function of temperature variation; the higher the value of $\mathrm{E}_{\mathrm{a}}$ the more sensible is the product to rheological changes (Steffe, 1996). As important as rheology is to know the sensory acceptance of the product by the consumer. In this context, sensory analysis is applied in the food industry in the development of new products, in quality control, and in the selection of instrumental methods that are correlated with sensory attributes (Dutcosky, 2013; Minim, 2013).

Due to its unique sensory characteristics, reports tell that tucupi has gained gastronomic recognition in other Brazilian states, as well as in other countries (Santos \& Pascoal, 2013). Nonetheless, there is no industrialized product yet that uses tucupi as raw material. In face of that, this research aimed to prepare and to evaluate the sensory characteristics of a tucupi creamy paste, as well as to characterize and assess its rheological behavior at different temperatures. 


\section{Materials and methods}

\subsection{Raw material}

The preparation of the creamy paste used unseasoned commercial tucupi, which was concentrated down to $30 \%$ solids in a rotary evaporator at $70{ }^{\circ} \mathrm{C}$ and $31.2 \mathrm{kPa}$ (vacuum). This process condition was defined in preliminary assays. The paste also used corn oil, cassava starch, commercial refined sugar (sucrose), sodium chloride, dried garlic powder and dried onion powder, all of which purchased in the local market (Belém, PA, Brazil).

\subsection{Obtaining the paste}

Four formulations were tested, in which the proportion of tucupi/water varied according to Table 1 . The methodology proposed by Babajide \& Olatunde (2010) was used in the production of the paste, with some modifications. The concentrated tucupi, cassava starch, corn oil, water, commercial refined sugar, sodium chloride, dried garlic powder and dried onion powder were weighed and mixed, followed by heating in a water bath at $90^{\circ} \mathrm{C}$ for approximately $10 \mathrm{~min}$ with constant stirring. The product was packed properly in sanitized plastic containers with lids and hot filling $\left(90^{\circ} \mathrm{C}\right)$ was performed, followed by cooling at $8{ }^{\circ} \mathrm{C}$ and storage under this temperature until analysis.

\subsection{Sensory evaluation}

The sensory analysis was developed with the approval of the Research Ethics Committee of the Federal University of Pará (CEP/ICS/UFPA) under protocol no. 1,123,945. The sensorial test was conducted in the morning and in the afternoon at UFPA's Sensory Analysis Laboratory, in individual booths, using white light, in order to allow the visualization of the products. The evaluation test of the product was performed by 102 judges who declared themselves to be tucupi consumers ( 59 female and 43 male), between 18 and 60 years old, selected among students and employees from UFPA.

Samples $(\approx 5 \mathrm{~g})$ were served at room temperature $\left(\approx 25^{\circ} \mathrm{C}\right)$ in $50 \mathrm{~mL}$ disposable cups and sliced breads were used as vehicle. The samples were coded with random three-digit codes and served monadically according to a design proposed by Macfie et al. (1989). Water at room temperature was provided in cups to

Table 1. Formulations tested for tucupi creamy paste.

\begin{tabular}{lcccc}
\hline \multirow{2}{*}{\multicolumn{1}{c}{ Ingredients }} & \multicolumn{4}{c}{ Formulation/composition (\%) } \\
\cline { 2 - 5 } & $\mathrm{P} 5$ & $\mathrm{P} 10$ & $\mathrm{P} 15$ & $\mathrm{P} 20$ \\
\hline Concentrated tucupi & 5 & 10 & 15 & 20 \\
Cassava starch & 7.5 & 7.5 & 7.5 & 7.5 \\
Corn oil & 10 & 10 & 10 & 10 \\
Water & 70 & 65 & 60 & 55 \\
Sodium chloride & 1.5 & 1.5 & 1.5 & 1.5 \\
Commercial refined sugar & 5 & 5 & 5 & 5 \\
Dried garlic powder & 0.5 & 0.5 & 0.5 & 0.5 \\
Dried onion powder & 0.5 & 0.5 & 0.5 & 0.5 \\
\hline
\end{tabular}

P5 - 5\% concentrated tucupi; P10 - 10\% concentrated tucupi; P15 - 15\% concentrated tucupi; P20 - 20\% concentrated tucupi. the judges in order to clean the palate between assessments and avoids sensory fatigue.

In order to verify the samples' acceptability of tucupi creamy paste, an acceptance test was applied using the 9-point hedonic scale, ranging from extreme "extremely liked" (score 9) to "extremely disliked" (score 1). The judges received an evaluation form for each sample and were asked to indicate, according to the hedonic scale, how much they liked or disliked the pastes. The samples' acceptability was used to rate the attributes color, aroma, flavor, texture and overall impression, evaluated in this order.

The results analysis used frequency distribution for the sensory scores of each attribute and overall impression according to the following acceptance ranges (Della Lucia, 2008): rejection region: scores from 1 to 5 (between the hedonic terms "disliked very much" and "neither like nor dislike"), which indicate that the judges did not like the sample; and acceptance region: scores from 6 to 9 (located between the hedonic terms "liked slightly" and "liked extremely"), which indicate that the judges liked the sample.

The analyses also assessed the acceptability index (AI) (Equation 1) and the intent of purchasing the product, which used a five-point scale from "definitely would not buy" (score 1) to "definitely would buy" (score 5) (Minim, 2013).

$A I(\%)=A_{m} \cdot 100 / B$

where $\mathrm{A}_{\mathrm{m}}=$ mean score obtained for the product and $\mathrm{B}=$ maximum score that the product may be rated (note 9 from the hedonic scale).

\subsection{Product characterization}

The product characterization analyzed moisture (method 925.09), ashes (method 923.03), lipids (method 920.85), proteins (nitrogen-protein conversion factor 6.25) (method 920.87), and chlorides (method 935.47) as described by the Association of Official Analytical Chemists (2010). Total soluble solids (TSS), total titratable acidity (TTA), and $\mathrm{pH}$ were determined by methodologies described by the Adolfo Lutz Institute (Instituto Adolfo Lutz, 2008). The total carotenoid content was determined by spectrophotometry with reading at $450 \mathrm{~nm}$ using petroleum ether as solvent (specific absorbance at 2,592) according to the methodology described by Rodriguez-Amaya (2001). The results were expressed in $\mu \mathrm{g}$ of $\beta$-carotene/g product. To calculate the energy value, the total carbohydrate content was determined from the difference (100 - (moisture + ashes + lipids + proteins) (Brasil, 2003). Instrumental color was determined by a Chroma Meter CR 400 Konica-Minolta digital colorimeter (Japan) using the CIE Lab system. The parameter $L^{\star}$, which defines luminosity $\left(L^{\star}=0\right.$ black; $L^{*}=100$ white $)$, and $a^{\star}$ and $b^{\star}$, responsible for chromaticity $\left(+a^{*}=\right.$ red and $-a^{*}=$ green; $+b^{*}=$ yellow and $-b^{\star}=$ blue), were assessed. The complete characterization was performed only in the best acceptance formulation, according to the sensorial evaluation results; however, for sake comparison, some properties of three commercial mustard pastes, as well as the commercial tucupi, concentrated tucupi and four pastes developed in this work were assessed. All analyses were performed 
in triplicate and the results were presented as the mean of the replicates.

Prior to the sensorial analysis, analysis as the presence of Salmonella spp. and coliforms at $45^{\circ} \mathrm{C}$ was performed in the product as recommend by Brazilian laws (Brasil, 2001), according to the methodology described in the Compendium of Methods for the Microbiological Examination of Foods (Downes \& Ito, 2001). The value of coliforms at $45^{\circ} \mathrm{C}$ is below $3 \mathrm{MPN} / \mathrm{g}$ and the absence of Salmonella indicated that the produced pastes was according to the delimits established by Brazilian laws (Brasil, 2001), assuring their security for consumption.

\subsection{Rheological measures}

The rheological behavior for the paste chosen by sensory evaluation was assessed according to Paredes et al. (1988), with some modifications. For measurements, a rheometer (Brookfield, R/S PLUS - SST, Massachusetts, USA) was used, coupled to a thermostatic bath (Lauda Ecoline, RE 200, New Jersey, USA) and connected to a computer system for data acquisition. The rheological data were obtained by the CR (control rate) ramp method with shear rate ranging from 0 to $350 \mathrm{~s}^{-1}$ (ramp up) and 350 to $0 \mathrm{~s}^{-1}$ (ramp down). A plate/plate system with C25-1 spindle and $1 \mathrm{~mm}$ gap was used. The rheological curves were obtained at 25,40 , and $60^{\circ} \mathrm{C}$. This temperature range was based on ambient and extreme storage temperatures. All assays were carried out in triplicate.

\subsection{Mathematical modeling}

The fits of the Newton (Equation 2), Bingham (Equation 3), Ostwald-de-Waele (Equation 4), and Herschel-Bulkley (Equation 5) (Steffe, 1996) models to the experimental data of paste rheology were assessed. The coefficient of determination $\left(\mathrm{R}^{2}\right)$, reduced chi-squared value $\left(\chi^{2}\right)$, and root mean square error $\left(R^{2}\right)$ were the parameters employed to assess fit precision.

$$
\begin{aligned}
& \tau=\eta \cdot \gamma \\
& \tau=\tau_{0}+\eta_{\mathrm{pl}} \cdot \gamma \\
& \tau=\mathrm{k} \cdot \gamma^{\mathrm{n}} \\
& \tau=\tau_{0}+\mathrm{k} \cdot \gamma^{\mathrm{n}}
\end{aligned}
$$

where, $\tau=$ shear stress $(\mathrm{Pa}) ; \tau_{0}=$ yield stress $(\mathrm{Pa}) ; \gamma=$ shear rate $\left(\mathrm{s}^{-1}\right)$; $\eta=\operatorname{viscosity}(P a . s) ; \eta_{p l}=$ plastic viscosity $(P a . s) ; k=$ consistency index $\left(\mathrm{Pa} . \mathrm{s}^{\mathrm{n}}\right)$; and $\mathrm{n}=$ behavior index.

The apparent viscosity values $\left(\eta_{a}\right)$ were calculated by Equation 6 , in which the values of $\tau$ were calculated with the model that best fit the experimental data of $\tau$ versus $\gamma$. Thus, the effect of temperature on apparent viscosity was assessed by employing an Arrhenius-like equation (Equation 7) (Steffe, 1996). The product's activation energy $\left(\mathrm{E}_{\mathrm{a}}\right)$ value was calculated from the angular coefficient of the slope $\eta_{\mathrm{a}}$ versus $1 / \mathrm{T}$ (Equation 8 ). The linear regression used values of $\eta_{a}$ determined for a shear rate of $100 \mathrm{~s}^{-1}$ for each working temperature $\left(25-60{ }^{\circ} \mathrm{C}\right)$. $\eta_{a}=\frac{\tau}{\gamma}$

$\eta_{a}=A \cdot e^{\frac{-E_{a}}{R T}}$

$\ln \eta_{a}=\ln A-\frac{E_{a}}{R} \cdot \frac{1}{T}$

where $\eta_{\mathrm{a}}=$ apparent viscosity (Pa.s); $\mathrm{A}=$ Arrhenius constant (non-dimensional); $\mathrm{E}_{\mathrm{a}}=$ activation energy $(\mathrm{kJ} / \mathrm{mol}) ; \mathrm{R}=$ universal gas constant $(8.314 \mathrm{~J} / \mathrm{mol} . \mathrm{K})$; and $\mathrm{T}=$ absolute temperature $(\mathrm{K})$.

\subsection{Statistical analysis}

Acceptance data of each attribute were submitted to analysis of variance (ANOVA) at significance level of 5\%, with sample and judge as sources of variation, using the software Statistica for Windows version 7.0. The Tukey test was applied to determine the differences in the samples' acceptance means in each attribute. The same software was used in the linear and non-linear regression analysis. In this case, Levenberg-Marquardt methodology and convergence criterion of $10^{-6}$ were employed.

Acceptability was evaluated by internal preference mapping technique (Macfie \& Thomson, 1988), where the acceptance scores were organized into a matrix of creamy pastes (lines) and judges (columns), which was submitted to Principal Component Analysis (PCA), the multivariate analysis technique. This technique allows representing the judges, graphically, into a two-dimensional space, which facilitates the interpretation of the results and considers each judge individually. The procedure was performed for each attribute (color, aroma, flavor, texture and overall impression) separately, and five maps were obtained. The results of the tucupi creamy pastes were expressed in a scatter plot and data correlations of each judge with first two main components. The software STAT/SAS 9.1 was used for this statistical analysis.

\section{Results and discussion}

\subsection{Sensory evaluation}

Acceptance and intent of purchase tests

The percentages of the scores of tucupi pastes in the acceptance and rejection regions for the attributes of color, aroma, flavor, texture, and overall impression are presented in Figure 1. High percentages of acceptance were observed for all attributes assessed and for overall impression, regardless of the formulation, and most judges classified the samples between "liked slightly" and "likes extremely."

No difference was found, at 5\% significance level, regarding color among the pastes with 10, 15, and 20\% tucupi. For aroma, the variations observed among the formulations were not statistically significant ( $\mathrm{p}>0.05)$. The means of flavor, texture, and overall impression of the pastes with 5, 10, and 15\% tucupi did not differ $(\mathrm{p}>0.05)$. Overall, the acceptability index values were above $70 \%$, which suggests all formulations had favorable repercussion (Monteiro, 1984; Dutcosky, 2013). 
Color

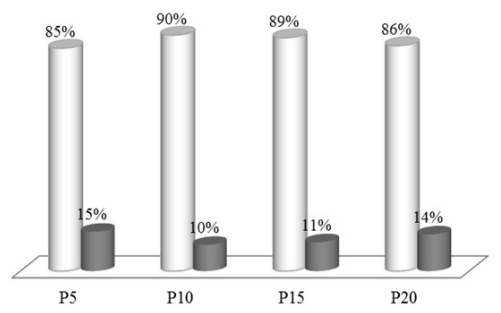

Texture

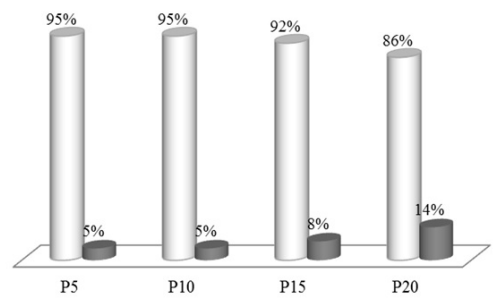

Aroma

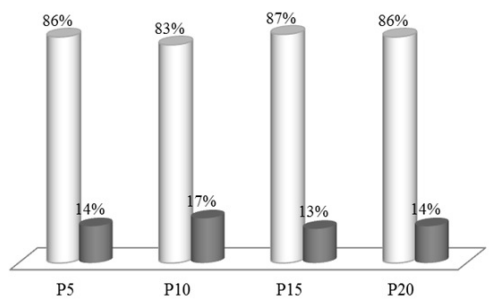

Flavor

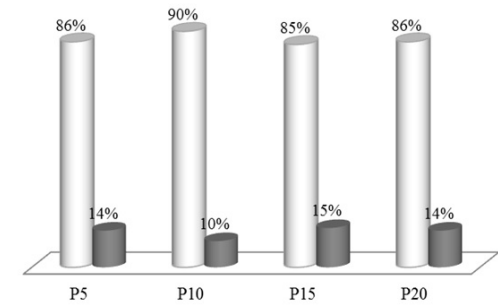

Overall impression

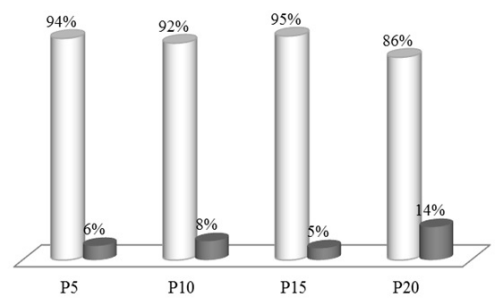

Figure 1. Histograms of the percentages of the acceptance and rejection regions regarding color, aroma, flavor, texture, and overall impression of the creamy tucupi paste with 5\% (P5), 10\% (P10), 15\% (P15), and 20\% (P20) concentrated tucupi. $\square$ Acceptance region (scores from 6 to 9 , between the hedonic terms "liked slightly" and "liked extremely"), a Rejection region (scores from 1 to 5, between the hedonic terms "disliked very much" and "neither like nor dislike")

The attributes scores of the produced creamy paste (minimum score of 6.3) were higher than the salad dressings elaborated by Babajide \& Olatunde (2010) with different concentrations of corn starch and cocoyam starch, which maximum score of these attributes was 5 in a 9-point hedonic scale.

According to Pelosi \& Azevedo-Meleiro (2014), products with maximum concentration of a specific added ingredient are well accepted by consumers. However, this research showed a rejection to creamy paste with $20 \%$ concentrated tucupi. The judges' comments on the unfavorable characteristics of the paste with $20 \%$ tucupi mentioned the following aspects: too intense tucupi flavor and characteristic color, less consistent texture, and too acidic flavor. Those comments justify the lower mean scores and acceptability indices for this formulation for most attributes analyzed. The acidic flavor was also an unfavorable characteristic observed for soy based creamy sauce formulated with soybean and sunflower oil and different thickeners (Campos et al., 2009).

The purchase intention scale test showed positive results for the intention to purchase the tucupi creamy paste since 99\% of the judges stated they would buy the product (Figure 2). The high percentage value for purchase intention is attributed to the high consumption of tucupi as raw material in the Northern region of Brazil (Santos \& Pascoal, 2013; Soentgen \& Hilbert, 2016). That index shows that using tucupi as raw material to prepare a creamy paste may be an excellent new alternative use of the product.

\section{Internal preference mapping}

Figures 3 and 4 present the internal preference maps generated for acceptance data of the different tucupi creamy paste formulations regarding color, aroma, flavor, texture, and overall impression. Each point in the graph represents the correlations among a judge's acceptance data and the first two principal components. In this way, each point is associated with a judge. According to Minim (2013), the acceptance's correlation data of the product may be explained by the statistical technique of principal components analysis, if the sum of the first two principal components is at least $70 \%$.

The correlation of judges with at least one of the components $(|r|>0.50)$ suggests a difference in the acceptance of the formulations. The points located in the central region of the plot are not correlated with any component and, therefore, do not discriminate the pastes on acceptance. Thus, the low concentration of the judges in the central region of the graphs 


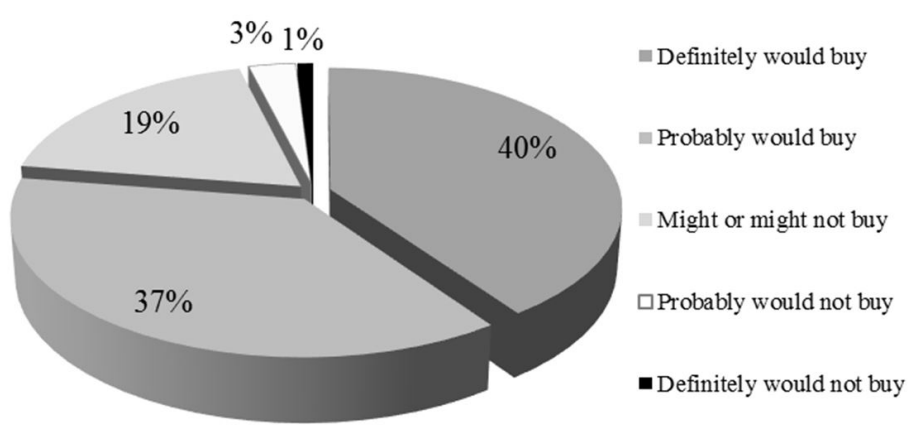

Figure 2. Purchase intention for the tucupi creamy paste.

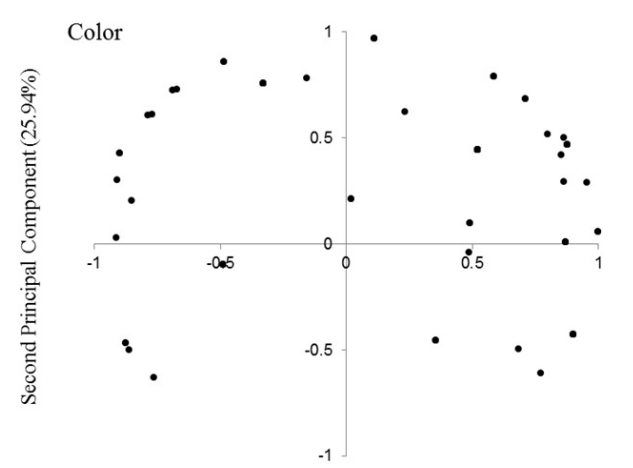

First Principal Component (60.11\%)

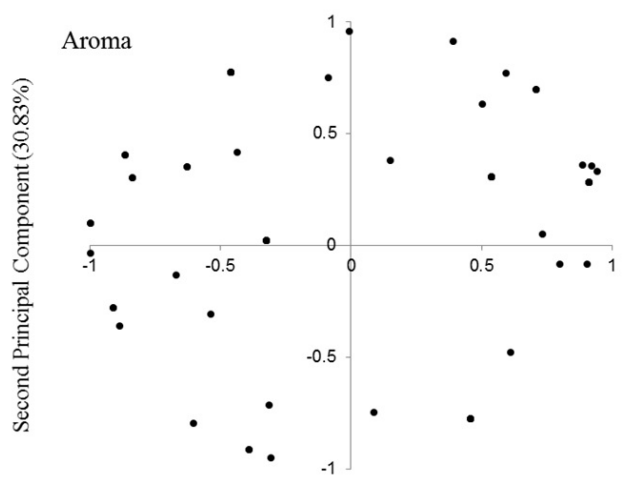

First Principal Component (49.87\%)

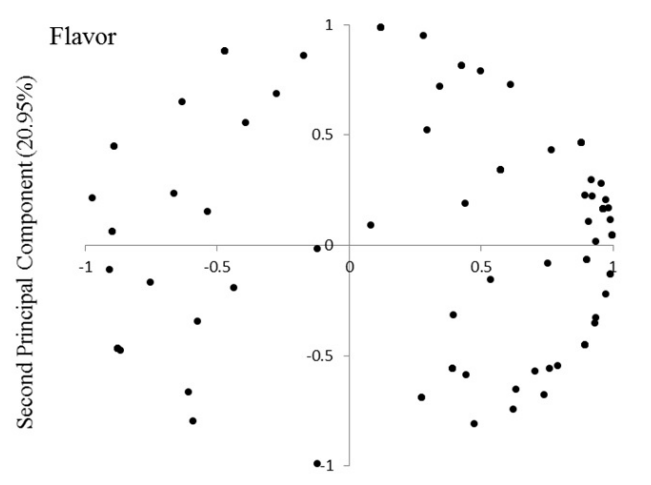

First Principal Component (64.85\%)

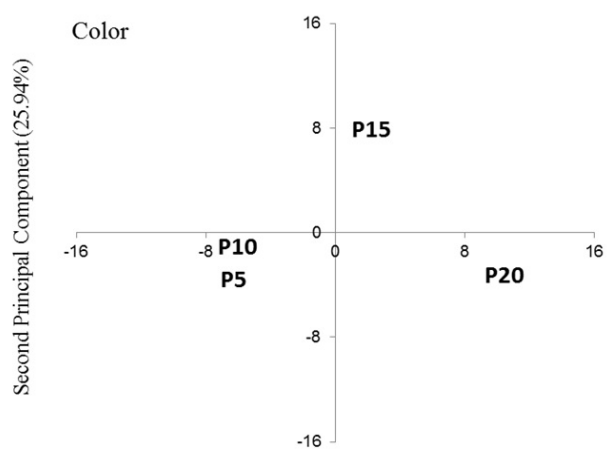

First Principal Component $(60.11 \%)$

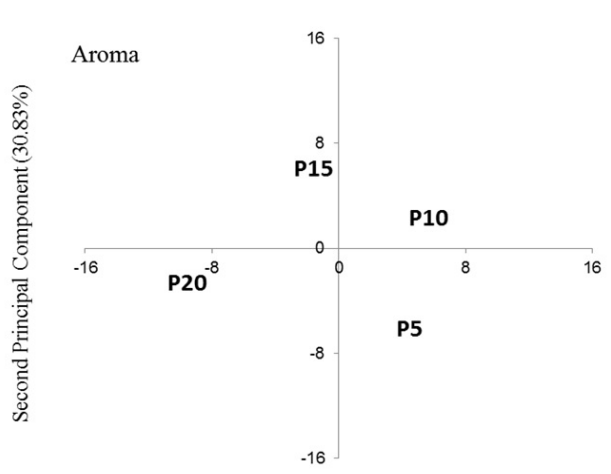

First Principal Component (49.87\%)

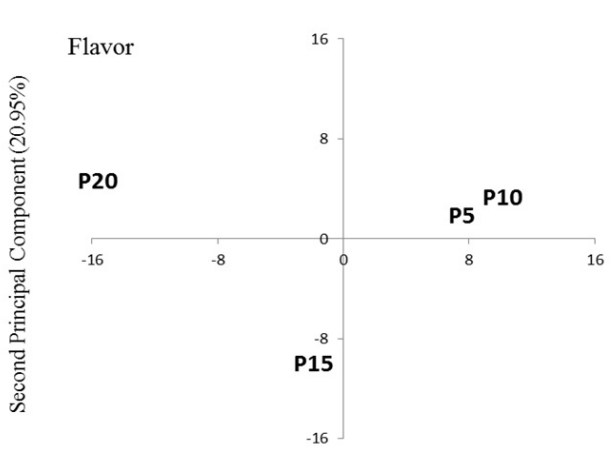

First Principal Component (64.85\%)

Figure 3. Graphical representation of the judges and tucupi creamy paste formulations for the two principal components regarding the attributes of color, aroma, and flavor. $(\bullet)$ judges; paste: 5\% (P5), 10\% (P10), 15\% (P15), and 20\% (P20) tucupi. 


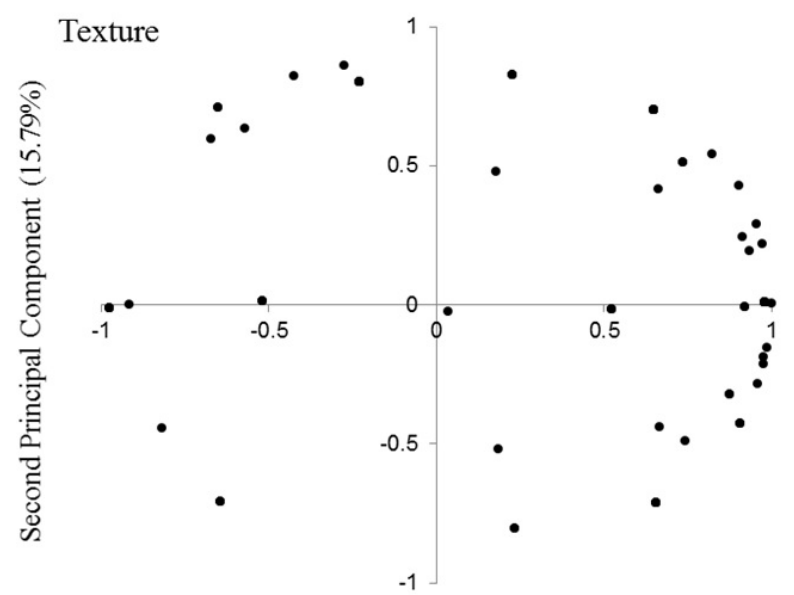

First Principal Component (74.07\%)

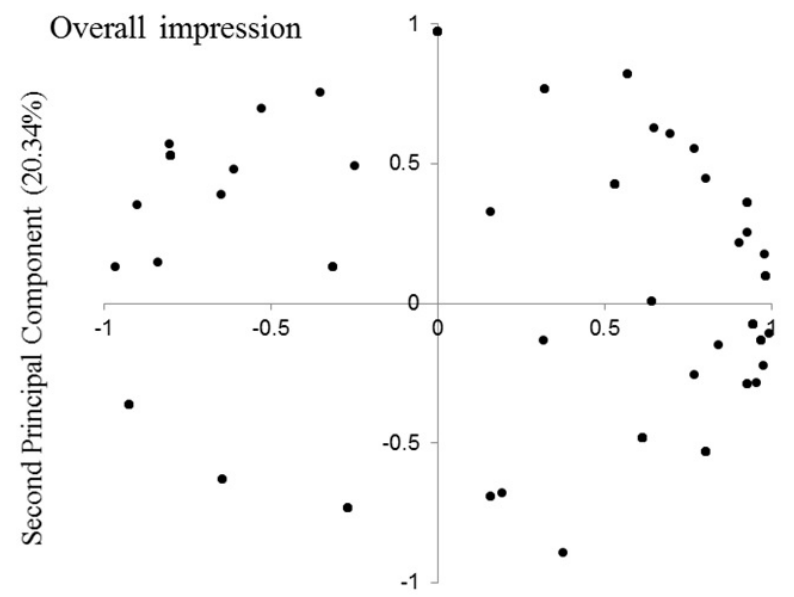

First Principal Component (62.60\%)

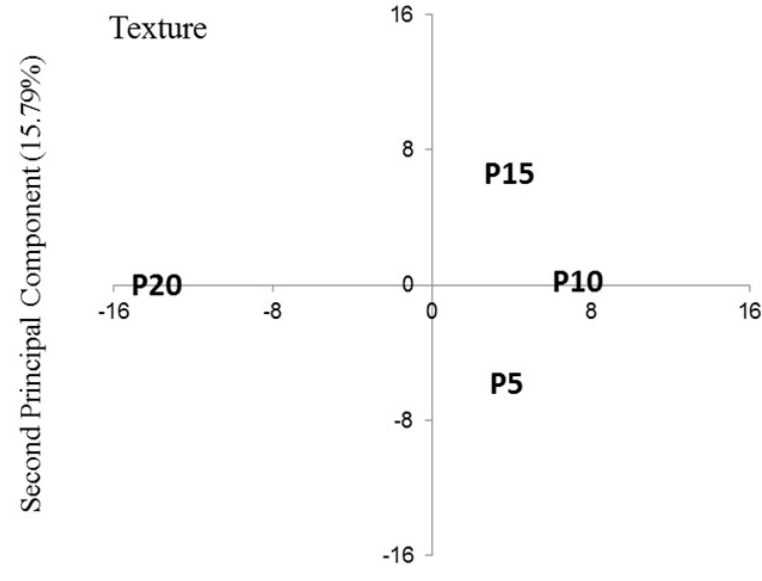

First Principal Component (74.07\%)

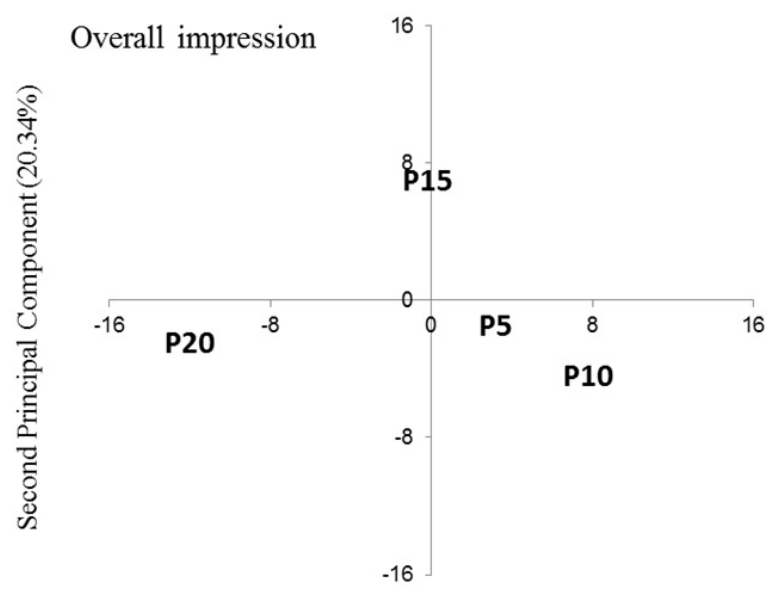

First Principal Component (62.60\%)

Figure 4. Graphical representation of the judges and tucupi creamy paste formulations for the two principal components regarding the attribute of texture and overall impression. (•) judges; paste: 5\% (P5), 10\% (P10), 15\% (P15), and 20\% (P20) tucupi.

indicates that most of them discriminated the samples, and they were able to differentiate the paste formulations in relation to the sensorial acceptance, with at least one of the main components correlated (Minim, 2013).

The spatial separation for the acceptance of the formulations suggests the existence of distinct groups, in relation to acceptance, for all attributes analyzed (Figures 3 and 4). That suggests the presence of tucupi in the paste caused noticeable changes in the product's sensory characteristics.

In the evaluation of the color attribute (Figure 3), the first principal component explained $60.11 \%$ and the second, $25.94 \%$ of the variability in responses, for a total of $86.05 \%$ of the variation in acceptance among the formulations. The spatial separation of the samples suggests the existence of three groups, the first consists of $15 \%$ tucupi, the second by $5 \%$ and $10 \%$ tucupi, suggesting that the judges did not differentiate these formulations. The $20 \%$ tucupi paste formed the third group. Most of the judges are positively correlated with the first principal component that indicates a better acceptance for creamy paste with 15\% tucupi, since there are more judges close to this sample.

Concerning aroma, four groups of judges were formed, who were spread among all quadrants of the plot, confirming that they did not identify a difference for this attribute among the formulations. The first principal component explained $49.87 \%$ of the data variability while the second component explained $30.83 \%$, for a total of $80.70 \%$ of the variation among the formulations.

For flavor, the first and second principal components explained $85.80 \%$ of the data variance, with the first principal component explaining the greatest variation $(64.85 \%)$ in responses. The spatial separation of the samples shows the formation of three groups, one formed by the 5 and $10 \%$ tucupi formulations and the other two by the 15 and 20\% tucupi formulations. These results indicated that samples P5 and P10 were the most accepted by the judges, since most are close to the group formed by them. This positioning suggests that the judges did not detect difference in the acceptance of the two samples. 
Creamy pastes P5 and P10, formulations with different levels of tucupi, obtained similar sensory acceptance when combined with different water contents, that is, 5\% tucupi and $70 \%$ water (P5) presented sensory acceptability for flavor equivalent to $10 \%$ tucupi and $65 \%$ water (P10) products. On the other hand, larger amounts of tucupi influenced negatively the acceptability for this attribute, due to the lower concentration of judges close to $15 \%$ and $20 \%$ tucupi pastes. Negative comments regarding the high acidity of P15 and P20 also reinforce their lower acceptance. These pastes had a total acidity of 17 and $22.94 \mathrm{mEq} \mathrm{NaOH} / 100 \mathrm{~mL}$, respectively, values higher than the acidity of the commercial tucupi $(7.7 \mathrm{mEq} \mathrm{NaOH} / 100 \mathrm{~mL})$, while for P5 and P10 the acidity was 6.17 and $11.91 \mathrm{mEq} \mathrm{NaOH/100} \mathrm{mL}$, values close from that determined for the commercial tucupi and those cited by Chisté et al. (2007), range 3.92 to $10.66 \mathrm{mEq} \mathrm{NaOH} / 100 \mathrm{~mL}$.

When texture (Figure 4) was analyzed, the spatial separation showed the formation of two distinct groups, one for the samples with 5\%,10\% and 15\% tucupi and the other for the sample with $20 \%$ tucupi. There is a higher concentration of judges close to the pastes of the first group, indicating that these products were more accepted. The high acidity of $20 \%$ tucupi paste destabilized the structure of the starch gel, which negatively influenced the texture of this paste. Studies have reported that the viscosity of cassava starch decreases under high acidity conditions (Sriburi \& Hill, 2000; Hirashima et al., 2005). According to Chisté et al. (2007), the commercial tucupi can be classified as a high acidity food; however, for P5, P10 and P15 pastes the starch gel remained stable. For this attribute, the first two components explain $89.86 \%$ of the variability in the responses. Campos et al. (2009) obtained a similar result on the sensory evaluation of the acceptance for soy based creamy sauce. The authors observed no significant difference between the three formulations elaborated for texture.

For overall impression, the two components explained $82.94 \%$ of the variation in responses and three distinct judge groups were observed between of four products. The first group is formed by the formulations P5 and P10, the second by the sample P15 and the third by the P20. A higher concentration of judges was observed close to the group formed by $5 \%$ and $10 \%$ of tucupi formulations, indicating that these were the most accepted; however, the judges did not perceive a difference in acceptance among them.

According to the internal preference mappings, the samples of tucupi paste most accepted in most of the attributes (flavor, texture and overall impression) were formulations P5 and P10. However, for the characterization of the product, $10 \%$ tucupi formulation was chosen by the fact that this sample is closer to the sample with $15 \%$ tucupi, which was the most accepted for the color attribute.

\subsection{Product characterization}

The paste with $10 \%$ tucupi had $\mathrm{pH}$ of 3.47 and titratable acidity of $11.91 \mathrm{mEqNaOH} / 100 \mathrm{~mL}$. Those results show that adding $10 \%$ tucupi with $30 \%$ solids is enough for this product to reach an unfavorable for bacterial activity $(\mathrm{pH}<4.5)$. However, in this $\mathrm{pH}$ condition fungi can develop in the product, which suggests the use of other preservatives or even maintaining the product under refrigeration (Alzamora, 1994). The $\mathrm{pH}$ of the tucupi paste was at the same order of magnitude observed for three commercial mustard pastes analyzed (mean of 3.28), however, the acidity of the product was much lower than that observed in the mustard samples (30.32 to $57.24 \mathrm{mEqNaOH} / 100 \mathrm{~mL}$ ).

The creamy paste composition was: $72.67 \%( \pm 0.11)$ moisture; $10.40 \%( \pm 0.27)$ lipids; $0.52 \%( \pm 0.01)$ proteins; $2.08 \%( \pm 0.01)$ ashes, of which $1.17 \%( \pm 0.05)$ chlorides; $14.33 \%( \pm 0.18)$ total carbohydrates, and $7.37 \mu \mathrm{g} / \mathrm{g}( \pm 0.38) \beta$-carotene. Moisture values of same order of magnitude were found by Ponka et al. (2014), in their studies, for 22 traditionally consumed sauces in Northern Cameroon (62.04-86.42\%); however, ashes (7.60-20.90\%) and proteins $(8.37-28.37 \%)$ values were higher than the tucupi creamy paste. The values of lipids in three french salad dressings (30.11, 36.09 and $37.42 \%)$ were higher than those for tucupi paste, but presented a value of the same order of magnitude for the carbohydrates (12.77-15.63\%) (Melo et al., 2015). The product had an energy value of $153 \mathrm{kcal} / 100 \mathrm{~g}$. This value was above those reported in the labels of the commercial mustard pastes ( 44.66 to $66.7 \mathrm{kcal} / 100 \mathrm{~g}$ ), however, close to the values observed in the labels of commercial ketchups (112 to $138 \mathrm{kcal} / 100 \mathrm{~g}$ ), both mentioned by the manufacturer.

The instrumental color analysis of the tucupi creamy paste yielded values of $53.38( \pm 0.46)$ for luminosity $(L)$, and $-6.58( \pm 1.09)$ and $42.33( \pm 2.04)$ for the chromaticity parameters $a^{*}$ and $b^{*}$, respectively. Those values were similar to the ones observed for commercial tucupi $\left(L=59.76 \pm 0.01 ; a^{*}=-2.71 \pm 0.12\right.$; $b^{\star}=45.82 \pm 0.08$ ), which shows the typical yellow color of tucupi was preserved in the product. Tucupi's yellow color is due by the presence of carotenoids (Marinho \& Arkcoli, 1981).

\subsection{Rheological evaluation}

Figure 5 presents the rheological curves of shear stress and viscosity versus shear rate for the creamy paste with $10 \%$ tucupi obtained at 25,40 , and $60^{\circ} \mathrm{C}$. This temperature range is similar to Koocheki et al. (2009), who evaluated rheological properties of ketchup $\left(25-55^{\circ} \mathrm{C}\right)$. The curves were built with the averages of the rheological data obtained in the assays with upward and downward shear rates. The decrease in the steepness of the flow curves (Figure 5A) as the shear rate increases suggests the product behaved as a non-Newtonian fluid with pseudoplastic characteristic at the temperature range studied. This behavior is confirmed by the reduction in product viscosity as the shear rate increases (Figure 5B) (Schramm, 2000). The same behavior was observed by Campos et al. (2009) for soy based creamy sauce and by Coutinho \& Cabello (2005) for cassava starch gels with $6 \%$ to $10 \%$ starch.

Table 2 presents the values of the parameters for the fits of the rheological models to the creamy paste's flow experimental data. The values of $\mathrm{R}^{2}, \chi^{2}$, and RMSE suggest the Newton model did not obtain a good fit to the rheological data, which is attributed to the product's non-Newtonian behavior (Steffe, 1996). In turn, the models of Bingham $\left(\mathrm{R}^{2}>0.986 ; \chi^{2}<277.875\right.$; RMSE $\left.<3.095\right)$, Ostwald-de-Waele $\left(\mathrm{R}^{2}>0.992 ; \chi^{2}<53.300 ; \mathrm{RMSE}<1.356\right)$, and Herschel-Bulkley $\left(\mathrm{R}^{2}>0.997 ; \chi^{2}<11.081\right.$; RMSE $\left.<0.434\right)$ had 

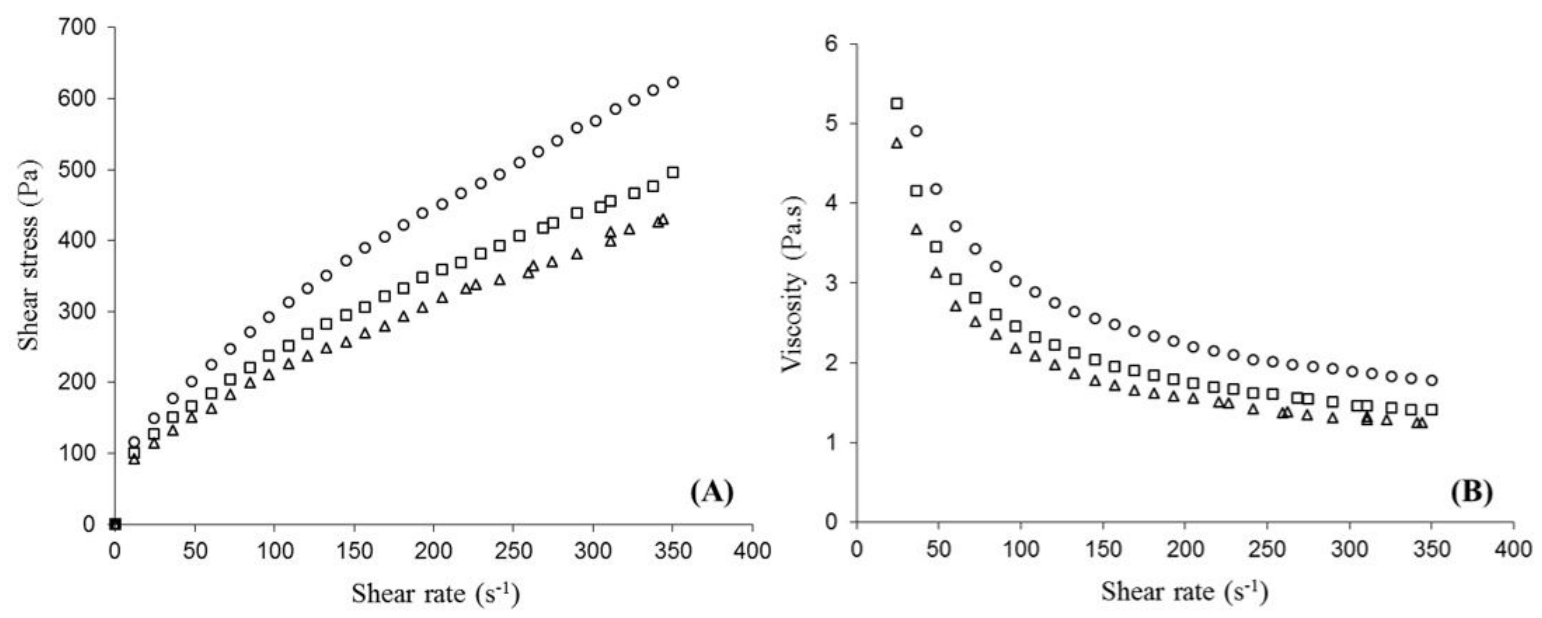

Figure 5. Effect of temperature on the shear stress (A) and viscosity (B) of the creamy paste with $10 \%$ tucupi. (०) $25^{\circ} \mathrm{C},(\square) 40{ }^{\circ} \mathrm{C},(\triangle) 60^{\circ} \mathrm{C}$.

Table 2. Values of the modeling parameters to the rheological data obtained for creamy paste with $10 \%$ tucupi at 25,40 , and $60{ }^{\circ} \mathrm{C}$.

\begin{tabular}{|c|c|c|c|c|}
\hline \multirow{2}{*}{ Model } & \multirow{2}{*}{ Parameter } & \multicolumn{3}{|c|}{ Rheological analysis temperature } \\
\hline & & $25^{\circ} \mathrm{C}$ & $40^{\circ} \mathrm{C}$ & $60^{\circ} \mathrm{C}$ \\
\hline \multirow{4}{*}{ Newton } & $\eta($ Pa.s $)$ & 2.044 & 1.616 & 1.429 \\
\hline & $\mathrm{R}^{2}$ & 0.753 & 0.692 & 0.687 \\
\hline & $\chi^{2}$ & $5,274.582$ & $3,836.480$ & $3,076.961$ \\
\hline & RMSE & 13.486 & 11.502 & 10.301 \\
\hline \multirow{5}{*}{ Bingham } & $\tau_{0}(\mathrm{~Pa})$ & 142.732 & 122.322 & 56.077 \\
\hline & $\eta_{\mathrm{pl}}($ Pa.s $)$ & 1.381 & 1.100 & 0.955 \\
\hline & $\mathrm{R}^{2}$ & 0.987 & 0.987 & 0.986 \\
\hline & $\chi^{2}$ & 277.875 & 263.574 & 115.748 \\
\hline & RMSE & 3.095 & 3.015 & 1.998 \\
\hline \multirow{5}{*}{$\begin{array}{l}\text { Ostwald-de- } \\
\text { Waele }\end{array}$} & $\mathrm{k}\left(\mathrm{Pa} \cdot \mathrm{s}^{\mathrm{n}}\right)$ & 22.487 & 20.768 & 18.634 \\
\hline & $\mathrm{n}$ & 0.526 & 0.540 & 0.534 \\
\hline & $\mathrm{R}^{2}$ & 0.997 & 0.996 & 0.992 \\
\hline & $\chi^{2}$ & 47.210 & 41.245 & 53.300 \\
\hline & RMSE & 1.276 & 1.193 & 1.356 \\
\hline \multirow{6}{*}{$\begin{array}{l}\text { Herschel- } \\
\text { Bulkley }\end{array}$} & $\tau_{0}(\mathrm{~Pa})$ & 55.461 & 54.374 & 52.733 \\
\hline & $\mathrm{k}\left(\mathrm{Pa} . \mathrm{s}^{\mathrm{n}}\right)$ & 10.767 & 8.407 & 7.800 \\
\hline & $\mathrm{n}$ & 0.680 & 0.673 & 0.697 \\
\hline & $\mathrm{R}^{2}$ & 0.999 & 0.999 & 0.997 \\
\hline & $\chi^{2}$ & 5.468 & 4.523 & 11.081 \\
\hline & RMSE & 0.434 & 0.395 & 0.618 \\
\hline
\end{tabular}

good fits and may be used to predict the product's flow curves under the conditions studied. The Ostwald-de-Waele model was the most efficient in predicting the rheological data of tomato sauce (Bhamidipati \& Singh, 1990) and soy based creamy sauce (Campos et al., 2009), whereas the Herschel-Bulkley model obtained the best fit to the rheological data of mustard and garlic sauces (Ikhu-Omoregbe \& Bushi, 2008).

The lower $\chi^{2}$ and RMSE values observed for the fits of the Herschel-Bulkley model allow stating that this model is able to more precisely predict the product's flow curves. This model was also able to predict the rheological behavior of four commercial chili sauces (Gamonpilas et al., 2011). Moreover, the Herschel-Bulkley model contemplates the calculation of the yield stress $\left(\tau_{0}\right)$, which is observed in the respective curves and decreased as temperature increased (Figure 5A). Knowing the value of $\tau_{0}$ is crucial for the processing of a fluid product (Steffe, 1996).

The behavior index (n) values predicted by the Ostwald-de-Waele and Herschel-Bulkley models confirm the non-Newtonian behavior of the creamy paste with $10 \%$ tucupi $(n \neq 1)$ and ratify the product's pseudoplastic behavior $(\mathrm{n}<1)$ in the experimental domain. The consistency index $(\mathrm{k})$, in turn, decreased as temperature increased, which is in accordance with the behavior observed for food fluids (Haminiuk et al., 2006).

The apparent viscosities calculated by the Herschel-Bulkley model for a shear rate of $100 \mathrm{~s}^{-1}$ were $2.94 \mathrm{~Pa}$.s at $25^{\circ} \mathrm{C}$, $2.41 \mathrm{~Pa} . s$ at $40{ }^{\circ} \mathrm{C}$, and 2.14 Pa.s at $60^{\circ} \mathrm{C}$. A similar trend was observed for tomato sauce (Bhamidipati \& Singh, 1990) and mustard paste (Bhattacharya et al., 1999). The value of the coefficient of determination $\left(R^{2}>0.96\right)$ suggested the Arrhenius equation (Equation 7) represented well the effect of temperature on apparent viscosity. The angular coefficient of the slope obtained from this coefficient was then used to calculate the activation energy $\left(E_{a}\right)$ value for the product, which was $7.49 \mathrm{~kJ} / \mathrm{mol}$. Higher $E_{a}$ values observed by Ikhu-Omoregbe \& Bushi (2008) for mustard $(11.94 \mathrm{~kJ} / \mathrm{mol})$ and garlic $(18.37 \mathrm{~kJ} / \mathrm{mol})$ sauces and by Bhamidipati \& Singh (1990) for tomato sauce ( 16.31 to $20.16 \mathrm{~kJ} / \mathrm{mol}$ ) suggest the viscosity of the tucupi creamy paste is less dependent on temperature compared to those other similar products.

\section{Conclusions}

The research results showed that all tucupi creamy paste formulations presented good sensory acceptance $(>70 \%)$, but according to the comments of the judges, formulations with more than $15 \%$ concentrated tucupi had negative influence on the flavor and texture of the product attributed to high acidity. The $10 \%$ concentrated tucupi creamy paste showed color and acidity similar to the commercial tucupi and, additionally, its purchase intention was $99 \%$. This formulation presented $7.37 \mu \mathrm{g} / \mathrm{g}$ of $\beta$-carotene and an energy value of $153 \mathrm{kcal} / 100 \mathrm{~g}$, and it is presented as a promising alternative to the use of tucupi. 
The paste has non-Newtonian fluid behavior with pseudoplastic characteristic and the Herschel-Bulkley model proved very efficient in predicting the product's flow curves. The Arrhenius-like equation described with good precision the dependence among the product's apparent viscosity and temperature, with activation energy of $7.49 \mathrm{~kJ} / \mathrm{mol}$ for the product.

\section{Acknowledgements}

The authors would like to thank Conselho Nacional de Desenvolvimento Científico e Tecnológico (CNPq, Brazil) for financial support (473898/2012-8).

\section{References}

Abdelrahim, K. A., Ramaswamy, H., Doyon, G., \& Toupin, C. (1994). Effects of concentration and temperature on carboxymethylcellulose rheology. International Journal of Food Science \& Technology, 29(3), 243-253. http://dx.doi.org/10.1111/j.1365-2621.1994.tb02066.x.

Alzamora, S. M. (1994). Fundamentos del método de conservación por factores combinados. In P. F. Maupoey, A. A. Grau \& A. C. Boix, (Eds.), Aplicacion de factores combinados en la conservacion de alimentos (pp. 1-26). Valencia: Universidade Politécnica de Valencia.

Association of Official Analytical Chemists - AOAC. (2010). Official methods of analysis of association of Official Analytical Chemists International (18th ed.). Arlington: AOAC.

Babajide, J. M., \& Olatunde, O. O. (2010). Proximate composition, rheology and sensory qualities of corn-cocoyam salad cream. World Journal of Dairy \& Food Sciences, 5(1), 25-29. http://dx.doi. org/10.4314/njns.v31i1.63892.

Bhamidipati, S., \& Singh, R. (1990). Flow behavior of tomato sauce with or without particulates in tube flow. Journal of Food Process Engineering, 12(4), 275-293. http://dx.doi.org/10.1111/j.1745-4530.1990.tb00055.x.

Bhattacharya, S., Vasudha, N. K. S., \& Murthy, K. (1999). Rheology of mustard paste: a controlled stress measurement. Journal of Food Engineering, 41(3-4), 187-191. http://dx.doi.org/10.1016/S02608774(99)00102-8.

Bortnowska, G., Krzeminska, N., \& Mojka, K. (2013). Effects of waxy maize and potato starches on the stability and physicochemical properties of model sauces prepared with fresh beef meat. International Journal of Food Science \& Technology, 48(12), 2668-2675. http:// dx.doi.org/10.1111/ijfs.12263.

Brasil, Ministério da Saúde. (2001, January 10). Regulamento técnico sobre padrões microbiológicos para alimentos ( $\mathrm{RDC} \mathrm{n}^{\circ} 12$, de 2 de janeiro de 2001). Diário Oficial [da] República Federativa do Brasil.

Brasil, Ministério da Saúde. (2003, December 24). Regulamento técnico sobre rotulagem nutricional de alimentos embalados (RDC $n^{\circ}$ 360, de 23 de dezembro de 2003). Diário Oficial [da] República Federativa do Brasil.

Campos, D., Antoniassi, R., Deliza, R., Freitas, S. C., \& Felberg, I. (2009). Molho cremoso à base de extrato de soja: estabilidade, propriedades reológicas, valor nutricional e aceitabilidade do consumidor. Ciência e Tecnologia de Alimentos, 29(4), 919-926. http://dx.doi.org/10.1590/ S0101-20612009000400033.

Chisté, R. C., Cohen, K. O., \& Oliveira, S. S. (2007). Study of tucupi physicochemical properties. Ciência e Tecnologia de Alimentos, 27(3), 437-440. http://dx.doi.org/10.1590/S0101-20612007000300002.

Coutinho, A. P. C., \& Cabello, C. (2005). Caracterização reológica da fécula de mandioca. Revista Raízes e Amidos Tropicais, 1, 40-48. http://dx.doi.org/10.17766/1808-981X.2005v1n1p40-48.

Della Lucia, S. M. (2008). Métodos estatísticos para avaliação da influência de características não sensoriais na aceitação, intenção de compra e escolha do consumidor (Ph.D. thesis). Universidade Federal de Viçosa, Viçosa.

Downes, F. P., \& Ito, K. (2001). Compendium of methods for the microbiologycal examination of Foods. Washington: American Public Health Association. http://dx.doi.org/10.2105/9780875531755.

Dutcosky, S. D. (2013). Análise sensorial de alimentos (4th ed.). Curitiba: Champagnat.

Gamonpilas, C., Pongjaruvat, W., Fuongfuchat, A., Methacanon, P., Seetapan, N., \& Thamjedsada, N. (2011). Physicochemical and rheological characteristics of commercial chili sauces as thickened by modified starch or modified starch/xanthan mixture. Journal of Food Engineering, 105(2), 233-240. http://dx.doi.org/10.1016/j. jfoodeng.2011.02.024.

Haminiuk, C. W. I., Sierakowski, M. R., Vidal, J. R. M. B., \& Masson, M. L. (2006). Influence of temperature on rheological behavior of whole Araçá pulp (Psidium cattleianum Sabine). LebensmittelWissenschaft + Technologie, 39(4), 427-431. http://dx.doi.org/10.1016/j. lwt.2005.02.011.

Hirashima, M., Takahashi, R., \& Nishinari, K. (2005). Effects of adding acids before and after gelatinization on the viscoelasticity of cornstarch pastes. Food Hydrocolloids, 19(5), 909-914. http://dx.doi. $\operatorname{org} / 10.1016 /$ j.foodhyd.2004.12.004.

Ikhu-Omoregbe, D., \& Bushi, G. M. (2008). Rheological characteristics of South African commercial sauces. International Journal of Food Science \& Technology, 43(12), 2230-2236. http://dx.doi.org/10.1111/ j.1365-2621.2008.01860.x.

Instituto Adolfo Lutz - IAL. (2008). Normas analíticas, métodos químicos e físicos para análises de alimentos. São Paulo: IAL.

Koocheki, A., Ghandi, A., Razavi, S. M. A., Mortazavi, S. A., \& Vasiljevic, T. (2009). The rheological properties of ketchup as a function of differenthydrocolloids and temperature. International Journal of Food Science \& Technology, 44(3), 596-602. http://dx.doi. org/10.1111/j.1365-2621.2008.01868.x.

Lagarrigue, S., \& Alvarez, G. (2001). The rheology of starch dispersions at high temperatures and high rates: a review. Journal of Food Engineering, 50(4), 189-202. http://dx.doi.org/10.1016/S0260-8774(00)00239-9.

Macfie, H. J. H., \& Thomson, D. M. H. (1988). Preference mapping and multidimensional scaling. In J. R. Piggot (Ed.), Sensory analysis of foods (2nd ed.). London: Elsevier.

Macfie, H. J., Bratchell, N., Greenhoff, K., \& Vallis, L. V. (1989). Designs to balance the effect of order of presentation and first-order carryover effects in hall tests. Journal of Sensory Studies, 4(2), 129-148. http://dx.doi.org/10.1111/j.1745-459X.1989.tb00463.x.

Marinho, H. A., \& Arkcoli, D. B. (1981). Estudo sobre carotenos em algumas variedades amazônicas de mandioca. Acta Amazonica, 11(1), 71-75. http://dx.doi.org/10.1590/1809-43921981111071.

Marques, P. T., Pérégo, C., Le Meins, J. F., Borsali, R., \& Soldi, V. (2006). Study of gelatinization process and viscoelastic properties of cassava starch: effect of sodium hydroxide and ethylene glycol diacrylate as cross-linking agent. Carbohydrate Polymers, 66(3), 396-407. http:// dx.doi.org/10.1016/j.carbpol.2006.03.028.

Melo, A. N. F., Souza, E. L., Araujo, V. B. S., \& Magnani, M. (2015). Stability, nutritional and sensory characteristics of French salad dressing made with mannoprotein from spent brewer's yeast. Lebensmittel-Wissenschaft + Technologie, 62(1), 771-774. http:// dx.doi.org/10.1016/j.lwt.2014.06.050.

Minim, V. P. R. (2013). Análise sensorial: estudos com consumidores (3rd ed.). Viçosa: Editora UFV.

Modesto, M. S., Jr., \& Alves, R. N. B. (2014). Rentabilidade da produção artesanal de derivados de mandioca: tucupi e goma (Boletim de Pesquisa e Desenvolvimento). Belém: Embrapa Amazônia Oriental. 
Monteiro, C. L. B. (1984). Técnicas de avaliação sensorial (2nd ed.). Curitiba: CEPPA-UFPR.

Nurul, I. M., Azemi, B. M. N. M., \& Manan, D. M. A. (1999). Rheological behavior of sago (Metroxylon sagu) starch paste. Food Chemistry, 64(4), 501-505. http://dx.doi.org/10.1016/S0308-8146(98)00145-9.

Paredes, M. D. C., Rao, M. A., \& Bourne, M. C. (1988). Rheological characterization of salad dressings. 1. Steady shear, thixotropy and effect of temperature. Journal of Texture Studies, 19(3), 247-258. http://dx.doi.org/10.1111/j.1745-4603.1988.tb00940.x.

Pelosi, M. S., \& Azevedo-Meleiro, C. H. (2014). Production of tomato paste with higher pro-vitamin A content: microbiological, physicochemical and sensorial evaluation. Revista Ceres, 61(6), 891-899. http://dx.doi.org/10.1590/0034-737X201461060002.

Ponka, R., Fokou, E., Kansci, G., Beaucher, E., Piot, M., Leonil, J., \& Gaucheron, F. (2014). Recipes, proximate and mineral compositions of some traditional sauces consumed in the Far North Region of Cameroon. International Food Research Journal, 21(4), 1589-1596.

Rao, M. A., \& Tattiyakul, J. (1999). Granule size and rheological behavior of heated tapioca starch dispersions. Carbohydrate Polymers, 38(2), 123-132. http://dx.doi.org/10.1016/S0144-8617(98)00112-X.
Rodriguez-Amaya, D. B. (2001). A guide to carotenoid analysis in foods. Washington: ILSI Press.

Santos, V. F. N., \& Pascoal, G. B. (2013). Aspectos gerais da cultura alimentar paraense. Revista da Associação Brasileira de Nutrição, 5(1), 73-80.

Schramm, G. (2000). A practical approach to rheology and rheometry (2nd ed.). Germany: Thermo Haake Rheology.

Sikora, M., Juszczak, L., Sady, M., \& Krawontka, J. (2003). Use of starch/ xanthan gum combinations as thickeners of cocoa syrups. Nahrung Food, 47(2), 106-113. PMid:12744288. http://dx.doi.org/10.1002/ food.200390019.

Soentgen, J., \& Hilbert, H. (2016). A química dos povos indígenas da América do Sul. Química Nova, 39(9), 1141-1150. http://dx.doi. org/10.21577/0100-4042.20160143.

Sriburi, P., \& Hill, S. E. (2000). Extrusion of cassava starch with either variations in ascorbic acid concentration or $\mathrm{pH}$. International Journal of Food Science \& Technology, 35(2), 141-154. http://dx.doi. org/10.1046/j.1365-2621.2000.00360.x.

Steffe, J. F. (1996). Rheological methods in food process engineering (2nd ed.). East Lansing: Freeman Press. 